I have tried to make clear that Professor Morgenthai believes that a realistic internationalism coincides with the nation's true interests. Those interests, of course, are the values represented in human individuals who are relatively free and relatively equal. It is the protection of those human values which is a present responsibility of the statesmen of nations; but it is also the responsibility of wise statesmen who are morally sensitive to seek new forms for the preservation and realization of human values as the old forms gradually lose their validity and become obsolete.

There is no doubt that Morgenthau's position has some serious weaknesses, notably his truncated view of history which derives from an inadequate epistemology and his value theory which absolutizes freedom, misunderstands the nature and role of morality, and is not consistent in its recognition of the moral ambiguity of power. But, aside from these problems -and they are undergoing reconsideration in his most recent thought-Hans Morgenthau has left us in his debt for the many insights which he has contributed to our understanding of international politics and America's role in it.

\footnotetext{
SAMUeL H. Macill Chaplain and Assistant Professor of Religion Dickinson College
}

\title{
"CATECHISH ON COMMUNISM"
}

New Haven, Conn. Sir: A review as misleading as that of Thomas Molnar, who criticized Herman F. Reissig's "How to Combat Communism" in May worldview, deserves further discussion in your pages. The reviewer appears to be the one confused, not Mr. Reissig.

If Mr. Molnar has some secret picture of the right approach to Communism beyond that of Mr. Reissig, who is no pacifist, no isolationist, and no pagan, wouldn't he tip his hand and let us in on it? His review doesn't do this.

Molnar worries about those who are so much less nationalistic than he, and so far liberal-left, as he would say, that he doesn't hesitate to imply the use of the term communist sympathizer may be appropriate. To his mind Reissig doesn't reckon with the "possibility that there might be dupes of Communism among the leftist and progressive pilgrims to Utopia." He leaves the impression, without spelling it out for us, that there is some way of dealing with the internal threat these people are supposed to represent other than the way which the Reissig parnphlet would foster-the way of free discussion. I am assuming we agree that the F. B. I. rightly deals with actual and potential espionage.

As Mr. Molnar puts it at one point, "The essential question is, "What constitutes freedom and what tactics may best serve it?" "One would assume that freedom actually consists partly in the freedom of such people as socialists, collectivists and Marxists to promote their own ideas of political economy along with the rest of us. To call them communist sympathizers is to beg the question. Freedom is sustained, that is, by arguing the ease on its merits when these people are around, rather than by the opposite tactic of treating them as subversive, as the radical right certainly does, and as Mr. Molnar is close to doing. Certainly they may be naive, they may be wrong, they may even be "cynical" in their use of the power-play in voluntary organizations (as also, incidentally, may be those whom Mr. Molnar would more willingly call idealists when they work within the parties, the unions, or the associations). Their ideologies may indeed be subversive to our democratic institutions if successful in winning popular support or public power.

However, one would assume that free exchange as to the strengths of our system, political, economic, social, and ideological, is precisely the way we fight "communism" of this sort. In attacking the radical right and its netrotic approach to this question, $\mathbf{M r}$. Reissig is proposing that alternative. If there is another way, we have a right to hear it from Mr. Molnar. (It is an old story now, from McCarthy days, but it comes to mind. An officer of the law, pursuing a naked Dukhobor, found that his own clothes were an impediment, and he caught the culprit to arrest him for indecent exposure only by'shedding progressively all his own apparel. To Mr. Reissig, un-freedom appears to be the proposal of the radical right as the means of arresting those who promote un-freedom.)

The other disturbing issue in the reviewer's mind is combatting communism on the international front. Without going into a paper on foreign policy, we may here also ask for some positive suggestions from his quarter. He argues the inadequacy of positions he calls "mere commencement address platitudes," but he doesn't tip his own hand. If NATO, and the Marshall Plan, if foreign aid and even the fight for better race relations on the domestic front, if an intelligent (not blind) dedication to the capabilities of the UN have not served us well in our opposition to international communism, we have a right to know from a critical review what has, A moratorium on criticism of Franco and continued colonialism are no answers at all, nor are proposals for quick liberation of those under communist zule.

Perhaps the work Molnar Ieviews was assuming 
too much understanding of these issues among the public; there is a deep gulf fixed between the one approach and the other, but the review did little in an. interpretive way to communicate across it. The Reissig pamphlet is an answer to the "anti-communist" of the radical right who fecl that others are not anticommunist. Conceivably the far right may reach serious proportions. The booklet is helping many church. men in their job of predenting that. It is not designed to be a book on the values and disvalues of the social systems this side of and beyond the Iron Curtain.

World society moves and changes rapidly now, and many of us are the forces in it. No devil-theory that lays the change to Mr. Khrushchev or to a failure of U:S. foreign policy will suffice, nor are there easy answers for our guidance when there is a Hungary or a Laos on the horizon. In the wish that there were, some who discover others with positions differing from their own in the tortuous search for policy tis-a-vis the communist power bloc make of them straw men and "communist sympathizers." Yet the others may be more in touch with the realities of the world situation than they.

The Reissig pamphlet is in touch: It is essentially a pamphlet on the domestic issue, inseparable as international issues are from it. The pamphlet represents calm and reason in an area of discourse that often generates more heat than light. Indeed one gains the impression that it would have received more approval Erom $\mathrm{Mr}_{\text {. }}$ Molnar had it damned the communist threat with more heat, even sacrificing some of the "platitudes" to gain the space: The platitudes, however, relate to work we have at hand in our own social structures, work which may provide a base at least for more on-going stability in foreign policy.

GAYLORD B. NoYCE

\section{Mr. Molnar Replies:}

Stockholm

Sir: My opinion remains unchanged that Mr. Reissig's pamphlet is childish and pointless, yet I wish he had more articulate defenders. This tebate could be then more searching, and, incidentally, some sharper accusations might be levelled against me than mere "confusion."

However, "confusion," "nationalistic," "right-winger," "neurotic" (I ami surveying my critic's arsenal) leave me indifferent. My comment on Mr. Reissig's pamphlet was and remains- that the author does not fully understand communism (see my quotation in the original piece) when he 1) suggests that we should let other nations try it out; 2) sees in some communist-advocated doctrines a needed corrective to our own selfishness; and 3) recommends that in fighting communism we should first rid ourselves of our own errors and evil deeds. These are the main points I remember. As I am writing this in Stockholm, I do not have the original text or my review with me:)

Let my critic's mind be at rest: I do not propose that Mr. Reissig's right to issue pamphlets on communism be revoked. Right-winger as I may be, I respect other people's right to speak, publish, teach and debate. But as a critic, I may perhaps be allowed to say that Mr. Reissig's approach to the problemwhich I best spell out here: communism as a doctrine, the existence of domestic subversion mostly by dupes, the adequacy of official safeguards, the do's and dont's in foreign policy vis-a-vis Soviet Russiais simplistic and naive. In other words, we to not deal here with the question of whether discussion is good or bad, but whether Mr. Reissig's contribution to the discussion is meaningful. In my opinion it is not.

Thus, I do not have to propose a better method than discussion, but rather that more knowledge and lucidity be brought to it.

Now to the second point. In answer to my critic's challenge I wish to announce that my book on The Two Faces of American Foreign Policy will be published this fall by Bobbs-Merrill. I cannot give here what he expects "from my quarter," that is "some positive suggestions about combatting communism on the international front." But even if I had space for it, it would prove useless. First, because my critic has me safely pigeonholed among neurotic rightwingers and holders of "devil-theories about Mr. Khrushchev"; second, because the terms and examples he uses stiow that he and $I$ are, indeed, in very different camps with little chance for dialogue. This can be well illustrated: he asks me to make "positive suggestions," then he remarks that there are no easy answers for the Laos problem. (I expected him to add Cuba too.) If I were to suggest an answer he obviously dislikes, he would retort that I am not in tonch with the realities of the world situation. Etc., etc.

No, I am not in Laos, but $I$ recently returned from Berlin, where I talked to local officials and journalists and made a thorough visit to many points of the Wall. I venture to guess that,my critic can see no casy answer for his guidance when. Berlin is "on the horizon," or that he will suggest that the answer is to open Prince Edward county's public schools to Negro children. If I say that American and Western troops ought to have knocked down the Wall on August 13 and that while race segregation is bad, it lias no relevance to our fight against communism, Mr. Noyce will reach for his adjectives. Thus he will have a"good conscience plus the feeling that he is "in touch." I shall not disturb him.

THOMas MOLNar 